\title{
Analisis produksi dan pendapatan petani kelapa dalam di Kecamatan Pengabuan Kabupaten Tanjung Jabung Barat
}

\author{
Khoirul Amin, Zulgani, Purwaka Hari Prihanto
}

Prodi Ekonomi Pembangunan, Fak. Ekonomi dan Bisnis,Universitas Jambi

Email Korespodensi: gzulgani@gmail.com

\begin{abstract}
The purpose of this research is to find out and analyze the socio-economic characteristics of coconut farmers in Pengabuan Subdistrict and to analyze factors affecting the production and income of coconut farmers in Pengabuan Subdistrict in West Tanjung Jabung Regency.The method used this research is quantitative descriptive methode. The data used in this study is primary data. The analytical tool used is multiple linear regression. The results showed that at a significance level of $10 \%$ only land area variable had a significant effect on coconut production in Pengabuan SubDistrict, Tanjung Jabung Barat District while labor, fertilizer and pest variables did not significantly influence the coconut production in Sub-District Pengabuan Tanjung Regency Jabung Barat. However, simultaneously the dependent variable significant influences of the production coconut in Pengabuan District, Tanjung Jabung Barat District. In terms of income, production, selling price, and management costs significantly influence the income of coconut farmers in Pengabuan District, both partially and simultaneousl in 10\% significant level.
\end{abstract}

Keywords: production, farmers, income, coconuts

\begin{abstract}
Abstrak
Adapun yang menjadi tujuan dari penelitian ini adalah Untuk mengetahui dan menganalisis karakteristik sosial ekonomi petani kelapa dalam di Kecamatan Pengabuan serta untuk melihat faktor faktor yang mempengaruhi produksi dan pendapatan petani kelapa dalam di Kecamatan Pengabuan di Kabupaten Tanjung Jabung Barat. Metode yang digunakan dalam penelitian ini adalah Metode Deskriftif Kuantitatif. Data yang digunakan dalam penelitian ini merupakan data primer. Alat analisis yang digunakan adalah regresi linier berganda. Hasil penelitian menunjukkan bahwa pada tingkat signifikansi $10 \%$ hanya variabel luas lahan yang memiliki pengaruh yang signifikan terhadap produksi kelapa dalam di Kecamatan Pengabuan Kabupaten Tanjung Jabung Barat sedangkan variabel tenaga kerja, pupuk dan hama tidak berpengaruh secara signifikan terhadap produksi kelapa dalam di Kecamatan Pengabuan Kabupaten Tanjung Jabung Barat. Namun, secara serentak variabel terikat tersebut berpengaruh secara signifikan terhadap produksi kelapa dalam di Kecamatan Pengabuan Kabupaten Tanjung Jabung Barat. Dari segi pendapatan, produksi, harga jual, dan biaya pengelolaan berpengaruh secara signifikan terhadap pendapatan petani kelapa dalam di Kecamatan Pengabuan baik secara parsial maupun secara serentak pada tingkat signifikansi $10 \%$
\end{abstract}

Kata Kunci: produksi, petani, pendapatan, kelapa 


\section{PENDAHULUAN}

Provinsi Jambi merupakan salah satu daerah penghasil kelapa di Indonesia. Produksi kelapa di Provinsi Jambi pada tahun 2013 sebesar 625.164 ton dengan luas panen sebesar 149.369 hektar dan produktivitas 42 ku/ha BPS Dalam Angka (2013). Hasil produksi panen petani kelapa diharapkan mampu meningkatkan APBD Provinsi Jambi. Pemerintah Provinsi Jambi mengupayakan akan adanya sentra perkebunan kelapa dalam yang sesuai dengan struktur tanah dan kondisi alam yang cocok untuk pertumbuhan kelapa dalam. Kebijaksanaan peningkatan produksi kelapa di Propinsi Jambi bukan hanya ditujukan untuk memenuhi kebutuhan produksi daerah saja, tetapi juga dimaksudkan untuk dapat memberikan sumbangan positif terhadap pengadaan produksi kelapa nasional. Keadaan produksi kelapa melalui usaha tani kelapa dalam intesifikasi di Propinsi Jambi. Tanaman kelapa di Provinsi Jambi terdapat di setiap kabupaten, salah satunya adalah kabupaten Tanjung Jabung Barat yang mempunyakan lahan pasang surut sangat cocok bagi kelapa tumbuh berkembang dengan hasil yang cukup baik (Arianto, 2018).

Pengembangan ekonomi wilayah Kabupaten Tanjung Jabung Barat terlihat bahwa peran sektor pertanian masih menjadi sektor unggulan perkebunan kelapa terhadap pembentukan PDRB, yaitu sebesar 44,67\% (BPS, 2012). Komoditas kelapa di Kabupaten Tanjung Jabung Barat memiliki luas areal mencapai 461.310 Hektar. Komoditas kelapa telah menempatkan Kabupaten Tanjung Jabung Barat sebagai Kabupaten penghasil kelapa terbesar kedua di Provinsi Jambi setelah Kabupaten Tanjung Jabung Timur (Arianto, 2018).

Salah satu perkebunan kelapa dalam di Kabupaten Tanjung Jabung Barat terletak di Kecamatan Pengabuan. Luas lahan perkebunan kelapa di Kecamatan Pengabuan diperkirakan sekitar 13.515 hektar dengan produksi 14.481 ton selama tahun 2017. Tanaman kelapa merupakan komoditas terbanyak yang ditanam oleh petani di Kecamatan Pengabuan disampung tanaman perkebunan kelapa sawit, karet, kopi dan pinang.

Jumlah produksi yang melimpah disertai dengan luas lahan yang luas tentu saja akan meningkatkan pendapatan petani. Pendapatan yang maksimum dalam perkebunan kelapa merupakan tujuan yang ingin dicapai petani, pendapatan petani kelapa maksimum tercapai jika penggunaan faktor produksi efisien. Kabupaten Tanjung Jabung Barat merupakan daerah potensial untuk pengembangan perkebunan kelapa di Provinsi Jambi, hal ini dapat dilihat dari luas lahan yang ada.

Adapun tujuan dari penelitian ini adalah 1) Mengetahui dan menganalisis karakteristik sosial ekonomi petani kelapa dalam di Kecamatan Pengabuan; 2) Mengetahui dan menganalisis faktor-faktor yang mempengaruhi produksi dan pendapatan petani kelapa dalam di Kecamatan Pengabuan.

\section{METODE}

\section{Jenis dan dan sumber data}

Jenis data yang digunakan adalah data primer yang bersumber dari kuesioner yang disebarkan ke responden penelitian yaitu petani kelapa dalam. Metode yang digunakan dalam penelitian ini adalah metode analisis deskriptif dan analisis kuantitatif.

\section{Analisis data}

Alat analisis yang digunakan adalah metode regresi linier berganda. Regresi linier berganda digunakan untuk melihat pengaruh antara dua atau lebih variabel bebas 
terhadap satu variabel terikat. Persamaan regresi berganda dalam bentuk persamaan sebagai berikut (Firdaus, 2011):

$$
\mathrm{Y}=\mathrm{a}+\mathrm{b}_{1} \mathrm{X}_{1}+\mathrm{b}_{2} \mathrm{X}_{2}+\ldots \ldots \mathrm{b}_{\mathrm{n}} \mathrm{X}_{\mathrm{n}}
$$

Selanjutnya model analisis regresi linier berganda tersebut ditransformasikan secara operasional sesuai dengan variabel penelitian sebagai berikut:

Model regresi linier berganda untuk melihat pengaruh luas lahan, tenaga kerja, jumlah pupuk, jumlah pembasmi hama terhadap produksi kelapa dalam di Kecamatan Pengabuan Kabupaten Tanjung Jabung Barat. Model regresi linier berganda tersebut adalah sebagai berikut:

Keterangan:

$$
P R O=\beta_{0}+\beta_{1} L L+\beta_{2} \mathrm{TK}+\beta_{3} \mathrm{PUPUK}+\beta_{34} \mathrm{HAMA}+\boldsymbol{\mu}
$$

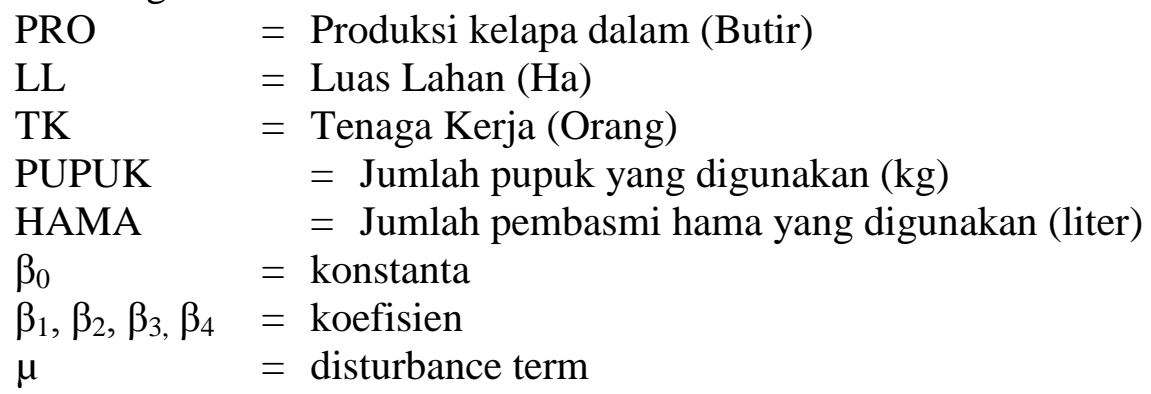

\section{HASIL DAN PEMBAHSAN}

\section{Karakteristik sosial ekonomi petani kelapa dalam Kecamatan Pengabuan Kabupaten Tanjung Jabung Barat. \\ Karakteristik sosial}

Karakteristik sosial responden dalam penelitian ini akan menggunakan petani kelapa dalam yang berjumlah 98 orang. Berdasarkan data tersebut, petani kelapa dalam dapat didefinisikan karakteristik sosialnya berdasarkan jumlah tanggunang, umur, jenis kelamin, tingkat pendidikan, pengalaman kerja.. Secara rinci karakteristik dari responden/ petani kelapa dalam Kecamatan Pengabuan Kabupaten Tanjung Jabung Barat adalah sebagai berikut :

\section{Karakteristik responden berdasarkan jumlah tanggunang}

Karakteristik responden berdasarkan jumlah tanggungan yang menjadi petani kelapa dalam Kecamatan Pengabuan Kabupaten Tanjung Jabung Barat dapat di lihat sebagai berikut :

Tabel 1. Karakteristik responden berdasarkan jumlah tanggungan

\begin{tabular}{llc}
\hline Jumlah Tanggungan & Jumlah Responden & Persentase (\%) \\
\hline 1 & 1 & 1,02 \\
2 & 12 & 12,25 \\
3 & 43 & 43,87 \\
4 & 36 & 36,74 \\
5 & 4 & 4,08 \\
6 & 2 & 2,04 \\
\hline Total & $\mathbf{9 8}$ & $\mathbf{1 0 0 , 0 0}$ \\
\hline
\end{tabular}

Sumber: Data yang diolah, 2018.

Responden yang memiliki jumlah tanggungan sebanyak 3 orang adalah 43 orang atau $43,87 \%$ dari total responden penelitian dan merupakan responden paling banyak 
memiliki jumlah tanggungan dalam keluarga. Responden paling sedikit yaitu 1 orang hanya memiliki jumlah tanggungan sebanyak 1 orang.

\section{Karakteristik responden berdasarkan umur}

Karakteristik responden berdasarkan umur yang menjadi petani kelapa dalam Kecamatan Pengabuan Kabupaten Tanjung Jabung Barat dapat di lihat sebagai berikut:

Tabel 2. Karakteristik responden berdasarkan umur

\begin{tabular}{ccc}
\hline Umur & JumlahResponden & Persentase (\%) \\
\hline $26-29$ & 12 & 12,25 \\
$30-33$ & 11 & 11,21 \\
$34-37$ & 14 & 14,29 \\
$38-41$ & 16 & 16,33 \\
$42-45$ & 13 & 13,27 \\
$46-49$ & 6 & 6,12 \\
$50-53$ & 7 & 7,14 \\
$54-57$ & 14 & 14,29 \\
$58-61$ & 5 & 5,10 \\
\hline Total & $\mathbf{9 8}$ & $\mathbf{1 0 0 , 0 0}$ \\
\hline
\end{tabular}

Sumber : Data yang diolah, 2018.

Berdasarkan Tabel 2 terlihat bahwa responden yang memiliki umur 26-29 tahun adalah sebanyak 12 orang atau sekitar $12,25 \%$. Jumlah responden yang memiliki umur 30-33 adalah sebanyak 11 orang atau sekitar $11,21 \%$. Jumlah responden yang memiliki umur 34-37 adalah sebanyak 14 orang atau sekitar 14,29\% dan merupakan umur dengan responden terbanyak kedua. Sedangkan umur dengan responden terbanyak pertama adalah umur 38-41 tahun sebanyak 16 orang atau sekitar $16,33 \%$ dari total responden penelitian. Responden dengan umur 46-49 tahun adalah sebanyak 6 orang atau $6,12 \%$ dan responden dengan umur 50-53 tahun adalah sebanyak 7 orang atau 7,14\%. Umur responden 54-57 sama banyaknya dengan umur responden 34-37 tahun yaitu 14 orang atau sekitar 14,29\% dari total responden penelitian. Umur dengan responden paling sedikit adalah 58-61 tahun yaitu hanya sebanyak 5 orang atau sekitar 5,1\%.

Karakteristik responden berdasarkan jenis kelamin

Karakteristik responden berdasarkan jenis kelamin yang menjadi petani kelapa dalam Kecamatan Pengabuan Kabupaten Tanjung Jabung Barat dapat di lihat sebagai berikut :

Tabel 3. Karakteristik responden berdasarkan jenis kelamin

\begin{tabular}{ccc}
\hline Jenis Kelamin & JumlahResponden & Persentase (\%) \\
\hline Laki-laki & 89 & 90,82 \\
Perempuan & 9 & 9,18 \\
Total & $\mathbf{9 8}$ & $\mathbf{1 0 0}$ \\
\hline
\end{tabular}

Sumber : Data yang diolah, 2018.

Berdasarkan Tabel 3. menjelaskan bahwa dari 64 responden petani kelapa dalam Kecamatan Pengabuan Kabupaten Tanjung Jabung Barat dengan jenis kelamin laki-laki menunjukkan jumlah sebanyak 89 orang atau $90,82 \%$, sedangkan yang jenis kelamin perempuan sebanyak 9 orang atau $9,18 \%$. 


\section{Karakteristik responden berdasarkan tingkat pendidikan}

Tingkat pendidikan petani kelapa dalam di Kecamatan Pengabuan terdiri dari Sekolah Dasar (SD), Sekolah Menengah Pertama (SMP), Sekolah Menengah Atas (SMA) dan Sarjana (S1). Sebagian besar masyarakat Kecamatan Pengabuan memiliki tingkat pendidikan hanya sampai sekolah dasar. Karakteristik respon berdasarkan tingkat pendidikan yang menjadi petani kelapa dalam Kecamatan Pengabuan Kabupaten Tanjung Jabung Barat dapat di lihat sebagai berikut :

Tabel 4. Karakteristik responden berdasarkan tingkat pendidikan

\begin{tabular}{lcc}
\hline Tingkat Pendidikan & Jumlah Responden & Persentase (\%) \\
\hline SD & 56 & 57,14 \\
SLTP & 20 & 20,41 \\
SLTA & 13 & 13,27 \\
S1 & 9 & 9,18 \\
\hline Total & $\mathbf{9 8}$ & $\mathbf{1 0 0 , 0 0}$ \\
\hline
\end{tabular}

Sumber : Data yang diolah, 2018.

Berdasarkan Tabel 4. menjelaskan bahwa dari 98 responden petani kelapa dalam di Kecamatan Pengabuan Kabupaten Tanjung Jabung Barat dengan tingkat pendidikan SD, SLTP, dan SLTA dan tingkat perguruan tinggi (S1) semuanya menjadi responden, dengan responden tingkat pendidikan SD menunjukkan jumlah sebanyak 56 orang atau $57,14 \%$, tingkat pendidikan SLTP berjumlah 20 orang atau 20,41\%, tingkat pendidikan SLTA berjumlah 13 orang atau 13,27\% dan tingkat pendidikan perguruan tinggi untuk S1 sebanyak 9 orang atau $9,18 \%$.

\section{Karakteristik Responden Berdasarkan Pengalaman Kerja}

Karakteristik responden berdasarkan pengalaman kerja yang menjadi petani kelapa dalama Kecamatan Pengabuan Kabupaten Tanjung Jabung Barat dapat di lihat sebagai berikut :

Tabel 5. Karakteristik responden berdasarkan pengalaman kerja

\begin{tabular}{ccc}
\hline Pengalaman Kerja (Tahun) & Jumlah Responden & Persentase $(\%)$ \\
\hline $5-10$ & 17 & 17,35 \\
$11-15$ & 32 & 32,65 \\
$16-20$ & 15 & 15,31 \\
$21-25$ & 15 & 15,31 \\
$26-30$ & 11 & 11,22 \\
$31-35$ & 7 & 7,14 \\
$36-40$ & 0 & 0 \\
$41-45$ & 1 & 1,02 \\
\hline Total & $\mathbf{9 8}$ & $\mathbf{1 0 0 , 0 0}$
\end{tabular}

Sumber : Data yang diolah, 2018.

Berdasarkan Tabel 5, reponden dengan pengalaman kerja 5-10 tahun adalah sebanyak 17 orang atau sekitar 17,35\% dan merupakan responden dengan pengalaman kerja paling banyak kedua. Responden dengan pengalam kerja paling banyak pertama adalah responden dengan pengalamankerja 11-15 tahun yaitu sebanyak 32 orang atau sekitar $32,65 \%$. Responden paling sedikit adalah responden yang memiliki pengalaman 
kerja 41-45 tahun yaitu hanya sebanyak 1 orang atau $1,02 \%$ dari total responden penelitian.

\section{Karakteristik ekonomi}

\section{Karakteristik respoden berdasarkan produksi kelapa dalam}

Karakteristik responden berdasarkan produksi kelapa dalam di Kecamatan Pengabuan Kabupaten Tanjung Jabung Barat dapat di lihat sebagai berikut :

Tabel 6. Karakteristik responden berdasarkan produksi kelapa dalam

\begin{tabular}{ccc}
\hline Produksi (Butir) & Jumlah Responden & Persentase (\%) \\
\hline $430-2.525$ & 34 & 34,69 \\
$2.526-4.620$ & 12 & 12,25 \\
$4.621-6.716$ & 21 & 21,44 \\
$6.717-8.812$ & 8 & 8,16 \\
$8.813-10.908$ & 7 & 7,14 \\
$10.909-13.004$ & 7 & 7,14 \\
$13.005-15.100$ & 7 & 7,14 \\
$15.101-17.196$ & 2 & 2,04 \\
\hline Total & $\mathbf{9 8}$ & $\mathbf{1 0 0}$
\end{tabular}

Sumber : Data yang diolah, 2018.

Berdasarkan Tabel 6, jumlah responden yang mampu memproduksi 430-2.525 butir adalah sebanyak 34 orang atau sekitar 34,69\% dan merupakan responden terbanyak yang memproduksi kelapa dalam di Kecamatan Pengabuan Kabupaten Tanjung Jabung Barat. Responden yang mampu memproduksi kelapa dalam terbanyak kedua adalah sebanyak 21 orang atau sekitar 21,44\%. Responden yang mampu memproduksi kelapa dalam sebanyak 15.101-17.196 butir kelapa dalam hanya sebanyak 2 orang atau sekitar 2,04\% dan merupakan responden dengan jumlah paling sedikit dalam memproduksi kelapa dalam.

\section{Karakteristik responden berdasarkan pendapatan}

Karakteristik responden berdasarkan pendapatan di Kecamatan Pengabuan Kabupaten Tanjung Jabung Barat dapat di lihat sebagai berikut :

Tabel 7. Karakteristik responden berdasarkan pendapatan

\begin{tabular}{rcc}
\hline Pendapatan $(\mathbf{R p})$ & Jumlah Responden & Persentase (\%) \\
\hline $387.000-2.058 .234$ & 33 & 33,67 \\
$2.058 .235-3.729 .470$ & 13 & 13,27 \\
$3.729 .471-5.400 .705$ & 18 & 18,37 \\
$5.400 .706-7.071 .941$ & 11 & 11,23 \\
$7.071 .942-8.743 .176$ & 7 & 7,14 \\
$8.743 .177-10.414 .411$ & 7 & 7,14 \\
$10.414 .412-12.085 .648$ & 7 & 7,14 \\
$12.085 .648-13.756 .882$ & 2 & 2,04 \\
\hline Rata-Rata & \multicolumn{2}{c}{$\mathbf{4 . 7 2 1 . 8 1 1 , 2 2}$}
\end{tabular}

Sumber : Data yang diolah, 2018. 
Berdasarkan Tabel 5.7, jumlah responden yang memiliki pendapatan paling sedikit yaitu 387.000-2.058.234 rupiah adalah 33 orang atau sekitar 33,67\% dan merupakan pendapatan dengan jumlah responden terbanyak. Responden dengan pendapatan yang berkisar antara 2.058.235-3.729.470 rupiah adalah sebanyak 12 orang atau $13,27 \%$. Pendapatan dengan jumlah responden terbanyak kedua adalah pendapatan yang berkisar antara 3.729.471-5.400.705 rupaiah yaitu sebanyak 18,37\% dari total jumlah responden. Responden dengan pendapatan berkisar antara 5.400.706-7.071.941 rupiah adalah sebanyak 11 orang atau 11,23\%. Pendapatan yang berkisar antara 7.071.942-8.743.176 rupiah, 8.743.177-10.414.411 rupiah dan 10.414.412-12.085.648 rupiah memiliki jumlah responden yang sama yaitu 7 orang atau sekitar $7,14 \%$. Pendapatan yang berkisar antara 12.085.648-13.756.882 rupiah merupakan pendapatan tertinggi dengan jumlah responden paling sedikit yaitu 2 orang atau 2,04\%.

\section{Karakteristik responden berdasarkan biaya pengelolaan}

Karakteristik responden berdasarkan biaya pengelolaan yang menjadi petani kelapa dalama Kecamatan Pengabuan Kabupaten Tanjung Jabung Barat dapat di lihat sebagai berikut :

Tabel 8. Karakteristik responden Berdasarkan Biaya Pengelolaan

\begin{tabular}{ccc}
\hline Biaya Pengelolaan (Rp) & Jumlah Responden & Persentase (\%) \\
\hline $982.000-3.911 .317$ & 19 & 19,39 \\
$3.911 .318-6.840 .635$ & 27 & 27,55 \\
$6.840 .636-9.769 .952$ & 13 & 13,27 \\
$9.769 .953-12.699 .270$ & 15 & 15,31 \\
$12.699 .271-15.628 .588$ & 3 & 3,06 \\
$15.628 .589-18.557 .906$ & 10 & 10,20 \\
$18.557 .907-21.487 .224$ & 6 & 6,12 \\
$21.487 .225-24.416 .541$ & 5 & 5,10 \\
\hline Rata-Rata & \multicolumn{3}{c}{$\mathbf{9 1 3 . 9 8 2 6 , 5 3}$}
\end{tabular}

Sumber: Data yang diolah, 2018.

Berdasarkan Tabel 5.8, responden yang mengeluarkan biaya pengelolan berkisar antara 982.000-3.911.317 rupiah adalah sebanyak 19 responden atau 19,39\%. Pengeluaran biaya pengelolaan yang berkisar antara 3.911.318-6.840.635 rupiah menjadi pengeluaran biaya pengelolaan dengan responden terbanyak yaitu 27 orang atau $27,55 \%$. Responden yang mengeluarkan biaya pengelolaan yang berkisar antara 6.840.636-9.769.952 rupiah adalah sebanyak 13 orang atau 13,27\%. Pengeluaran biaya pengelolaan yang berkisar antara 9.769.953-12.699.270 rupiah dilakukan oleh 15 orang responden atau $15,31 \%$. Pengeluaran biaya pengelolan yang berkisar antara 12.699.27115.628.588 rupiah dilakukan oleh 3 orang responden dan merupakan pengeluaran biaya pengelolan dengan responden paling sedikit.

\section{Karakteristik responden berdasarkan luas lahan}

Karakteristik responden berdasarkan luas lahan yang menjadi petani kelapa dalam di Kecamatan Pengabuan Kabupaten Tanjung Jabung Barat dapat di lihat sebagai berikut : 
Tabel 9. Karakteristik responden berdasarkan luas lahan

\begin{tabular}{ccc}
\hline Luas Lahan (Hektar) & JumlahResponden & Persentase (\%) \\
\hline $1-3$ & 21 & 21,43 \\
$4-6$ & 23 & 23,47 \\
$7-9$ & 16 & 16,33 \\
$10-12$ & 11 & 11,22 \\
$13-15$ & 6 & 6,12 \\
$16-18$ & 6 & 6,12 \\
$19-21$ & 10 & 10,20 \\
$22-24$ & 5 & 5,10 \\
\hline Total & $\mathbf{9 8}$ & $\mathbf{1 0 0 , 0 0}$ \\
\hline
\end{tabular}

Sumber : Data yang diolah, 2018.

Responden yang memiliki lahan seluas 4-6 hektar adalah sebanyak 23 orang atau sekitar $23,47 \%$ dan merupakan luas lahan yang memiliki responden terbanyak. Luas lahan yang berkisar antara 7-9 hektar dimiliki oleh 16 orang atau 16,33\%. Lahan dengan luas yang berkisar antara 10-12 hektar dimiliki oleh 11 orang responden atau $11,22 \%$. Responden dengan jumlah yang sama yaitu 6 orang atau $6,12 \%$ memiliki lahan dengan luas13-15 hektar dan 16-18 hektar. Responden dengan luas lahan yang berkisar antara 19-21 hektar adalah sebanyak 10 orang dan responden dengan luas lahan seluas 22-24 hektar adalah sebanyak 5 orang atau 5,10\%.

\section{Karakteristik responden berdasarkan jumlah tenaga kerja}

Karakteristik responden berdasarkan jumlah tenaga kerja yang menjadi petani kelapa dalam Kecamatan Pengabuan Kabupaten Tanjung Jabung Barat dapat di lihat sebagai berikut :

Tabel 10. Karakteristik responden berdasarkan jumlah tenaga kerja

\begin{tabular}{ccc}
$\begin{array}{c}\text { Jumlah Tenaga } \\
\text { Kerja (Orang) }\end{array}$ & Jumlah Responden & Persentase (\%) \\
\hline 0 & 1 & 1,02 \\
1 & 12 & 12,24 \\
2 & 43 & 43,88 \\
3 & 36 & 36,73 \\
4 & 4 & 4,08 \\
5 & 2 & 2,04 \\
6 & 0 & 0,00 \\
7 & 0 & 0,00 \\
Total & & $\mathbf{1 0 0 , 0 0}$ \\
\hline
\end{tabular}

Sumber : Data yang diolah, 2018.

Berdasarkan Tabel 10, responden yang tidak menggunakan tenaga kerja hanya ada 1 orang atau $1,02 \%$ dan merupakan responden paling sedikit dalam penggunaan tenaga kerja. Responden yang menggunakan 1 orang tenaga kerja adalah sebanyak 12 orang atau $12,24 \%$. Responden yang menggunakan 2 orang tenaga kerja merupakan responden terbanyak yaitu 43 orang atau $43,88 \%$. Jumlah responden terbanyak kedua adalah responden yang menggunakan 3 orang tenaga kerja yaitu sebanyak 36 orang atau $36,73 \%$. Responden lainnya menggunakan 4 dan 5 orang tenaga kerja dengan jumlah responden 4 dan 2 rang atau 4,08\% atau 2,04\%. 
Faktor-faktor yang mempengaruhi produksi dan pendapatan petani kelapa dalam di Kecamatan Pengabuan Kabupaten Tanjung Jabung Barat.

Hasil pengolahan regresi linier berganda dengan bertujuan untuk menentukan faktor-faktor yang mempengaruhi produksi dan pendaptan petani kelapa dalam di Kecamatan Pengabuan Tanjung Jabung Barat. Penelitian ini memiliki dua model regresi yang akan diestimasi. Model regresi linier berganda yang pertama adalah model regresi linier berganda yang menggunakan produksi kelapa dalam sebagai variabel terikat sedangkan luas lahan, tenaga kerja, jumlah pupuk dan jumlah pembasmi hama sebagai variabel bebas. Model regresi yang kedua adalah model regresi yang menggunakan pendapatan petani sebagai variabel terikat dan produksi, harga dan biaya pengelolaan sebagai variabel bebas.

\section{Produksi}

Model regresi linier berganda yang pertama menggunakan produksi kelapa dalam sebagai variabel terikat dan luas lahan, tenaga kerja, julah penggunaan pupuk dan jumla penggunaan pembasmi hama sebagai variabel bebas. Hasil estimasi model regresi linier berganda dengan menggunakan eviews 9.0 adalah sebagai berikut:

Tabel 11. Hasil regresi linier berganda

\begin{tabular}{crrrr}
\hline Variable & Coefficient & Std. Error & \multicolumn{1}{c}{ t-Statistic } & \multicolumn{1}{c}{ Prob. } \\
\hline C & 64,97614 & 266,1784 & 0,244108 & 0,8077 \\
LL & 637,8810 & 73,45718 & 8,683712 & 0,0000 \\
TK & $-64,03417$ & 95,21993 & $-0,672487$ & 0,5029 \\
PUPUK & 0,754558 & 0,570449 & 1,232744 & 0,1892 \\
HAMA & $-91,69524$ & 62,84197 & $-1,259140$ & 0,1479 \\
R-squared & 0,966256 F-statistic & 665,7515 \\
& \multicolumn{3}{c}{ Prob(F-statistic) } & 0,000000 \\
\hline
\end{tabular}

Sumber :Data diolah Tahun,2019

Hasil pengolahan data dengan menggunakan Eviews versi 9.0 di peroleh regresi linier berganda untuk menghitung produksi kelapa dalam di Kecamatan Pengabuan Kabupaten Tanjung Jabung Barat yang di pengaruhi dengan variabel bebas diantaranya luas lahan, tenaga kerja, jumlah pupuk, jumlah pembasmi hama. Persamaan regresi sebagai berikut :

\section{Pro $=64,97614+637,8810 \mathrm{LL}-64,03417 \mathrm{TK}+0,754558$ PUPUK-91,69524HAMA}

Hasil pengolahan data di peroleh nilai konstanta sebesar 64,97614 dan bertanda positif yang berarti jika luas lahan, tenaga kerja, jumlah pupuk, jumlah pembasmi hama bersifat tetap atau tidak berubah maka jumlah produksi kelapa dalam akan meningkat sebesar 65 butir. Koefisien regresi luas lahan sebesar 637,8810 dan bertanda positif artinya apabila luas lahan mengalami peningkatan sebesar 1 hektar maka jumlah produksi kelapa dalam akan meningkat sebesar 638 butir. Koefisien regresi tenaga kerja sebesar 64,03417 dan bertanda negatif artinya apabila terjadi penambahan tenaga kerja maka produksi kelapa dalam akan berkurang sebanyak 64 butir. Koefisien pupuk sebesar 0.754558 dan bertanda positif artinya, apabila pemberian pupuk meningkat sebesar $100 \mathrm{~kg}$ per hektarnya maka produksi kelapa dalam akan meningkat sebesar 76 butir kepala. Koefisien hama sebesar 91.69524 dan bertanda negative artinya apabila terjadi peningkatan pada penggunaan pembasmi hama seperti pestisida ataupun herbisida sebesar satu liter maka produksi kelapa dalam akan mengalami penurunan sebesar 91 butir. 


\section{Pengujian hipotesis \\ Uji simultan ( Uji F )}

Uji $\mathrm{F}$ digunakan untuk mengetahui semua variabel independen yang terdapat dalam persamaan regresi secara bersama-sama mempengaruhi variabel dependen. Pengujian dilakukan dengan membandingkan nilai $F$ hitung dengan $F$ tabel menggunakan tingkat keyakinan $90 \%(\alpha=10 \%)$. Hasil perhitungan diperoleh nilai $\mathrm{F}$ hitung sebesar 665,7515 dengan p-value sebesar 0.000000, dan nilai $\mathrm{F}$ tabel sebesar 2,65 . Oleh karena $F$ hitung $(665,7515)>F$ tabel $(2,65)$ dapat disimpulkan bahwa terdapat pengaruh yang signifikan produksi kelapa dalam di Kecamatan Pengabuan Kabupaten Tanjung Jabung Barat pada tingkat keyakinan $90 \%$.

\section{Uji parsial (Uji t)}

Pengujian secara parsial atau uji t dimaksudkan untuk mengetahui apakah variabel-variabel independen secara sendiri-sendiri berpengaruh nyata atau tidak terhadap variabel dependen. Dalam penelitian ini menggunakan uji 2 arah. Dengan keyakinan 90\% $(\alpha=10 \%)$ serta derajat kebebasan (df) sebesar 92, maka t tabel diperoleh 1,290. luas lahan (LL) adalah sebesar 8.683712 dengan probabilita sebesar 0,0000. Nilai t-hitung (8.683712) lebih besar dari t-tabel $(1,290)$ artinya luas lahan berpengaruh secara signifikan terhadap produksi kelapa dalam di Kecamatan Pengabuan Kabupaten Tanjung Jabung Barat. Hal ini juga dapat dilihat dengan cara membandingkan nilai probabilita t-hitung dengan tingkat $\alpha=10 \%$. Nilai probabilita thitung $(0,0000)$ variabel luas lahan lebih kecil dibandingkan dengan tingkat $\alpha=10 \%$, artinya variabel luas lahan berpengaruh secara signifikan terhadap produksi kelapa dalam. teanga kerja (TK) adalah sebesar |-0.672487| dengan probabilita sebesar 0.5029. Nilai t-hitung (|-0.672487|) lebih kecil dari t-tabel $(1,290)$ artinya tenaga kerja tidak berpengaruh secara signifikan terhadap produksi kelapa dalam di Kecamatan Pengabuan Kabupaten Tanjung Jabung Barat. Hal ini juga dapat dilihat dengan cara membandingkan nilai probabilita t-hitung dengan tingkat $\alpha=10 \%$. Nilai probabilita $t-$ hitung (0.5029) variabel tenaga kerja lebih besar dibandingkan dengan tingkat $\alpha=10 \%$, artinya variabel tenaga kerja tidak berpengaruh secara signifikan terhadap produksi kelapa dalam. Jumlah pupuk yang digunakan (PUPUK) adalah sebesar 1.232744 dengan probabilita sebesar 0.1892. Nilai t-hitung 1.232744 lebih kecil dari t-tabel $(1,290)$ artinya Jumlah pupuk yang digunakan (PUPUK) tidak berpengaruh secara signifikan terhadap produksi kelapa dalam di Kecamatan Pengabuan Kabupaten Tanjung Jabung Barat. Hal ini juga dapat dilihat dengan cara membandingkan nilai probabilita t-hitung dengan tingkat $\alpha=10 \%$. Nilai probabilita t-hitung $(0.1892)$ variabel tenaga kerja lebih besar dibandingkan dengan tingkat $\alpha=10 \%$, artinya variabel Jumlah pupuk yang digunakan (PUPUK) tidak berpengaruh secara signifikan terhadap produksi kelapa dalam. Jumlah pembasmi hama yang digunakan (HAMA) adalah sebesar |1.259140| dengan probabilita sebesar 0.1479. Nilai t-hitung |-1.259140| lebih kecil dari t-tabel $(1,290)$ artinya Jumlah pembasmi hama yang digunakan (HAMA) tidak berpengaruh secara signifikan terhadap produksi kelapa dalam di Kecamatan Pengabuan Kabupaten Tanjung Jabung Barat. Hal ini juga dapat dilihat dengan cara membandingkan nilai probabilita t-hitung dengan tingkat $\alpha=10 \%$. Nilai probabilita thitung (0.1479) variabel tenaga kerja lebih besar dibandingkan dengan tingkat $\alpha=10 \%$, artinya variabel Jumlah pembasmi hama yang digunakan (HAMA) tidak berpengaruh secara signifikan terhadap produksi kelapa dalam.

\section{Koefisien determinasi $\left(\mathbf{R}^{2}\right)$}

Koefisisen Determinasi bertujuan untuk melihat seberapa besar kemampuan variabel bebas dalam mempengaruhi variabel terikat. Satuan yang digunakan dalam 
koefisien determinasi biasanya adalah persen. Koefisien Deteminasi $\mathrm{R}^{2}$ dapat diketahui sejauh mana variabel luas lahan, tenaga kerja, jumlah pupuk, jumlah pestisida mampu mempengaruhi produksi kelapa dalam di Kecamatan Pengabuan Kabupaten Tanjung Jabung Barat. Semakin mendekati nilai 1 atau 100\% maka semakin besar pengaruh variabel independen terhadap variabel dependen. Berdasarkan hasil regresi linier berganda diperoleh R-square sebesar 0.966256 atau 96,63\%. Hal ini menunjukkan bahwa persentase pengaruh variabel independen (luas lahan, tenaga kerja, jumlah penggunaan pupuk dan jumlah pembasmi hama) terhadap variabel dependen (produksi kelapa dalam) sebesar 96,63\%. Sedangkan 3,37\% dipengaruhi oleh variabel yang belum diteliti dalam penelitian ini.

\section{Pendapatan}

Model regresi linier berganda yang kedua menggunakan pemdapatan petani sebagai variabel terikat dan produksi, harga dan biaya pengelolaan sebagai variabel bebas. Hasil estimasi model regresi linier berganda dengan menggunakan eviews 9.0 adalah sebagai berikut:

Tabel 12. Hasil regresi linier berganda

\begin{tabular}{crrrr}
\hline Variable & Coefficient & \multicolumn{1}{c}{ Std. Error } & \multicolumn{1}{c}{ t-Statistic } & \multicolumn{1}{c}{ Prob. } \\
\hline C & -2898315. & 330292.3 & $-8,775000$ & 0,0000 \\
PRO & 794,0736 & 8,314258 & 95,50746 & 0,0000 \\
HJ & 3510,737 & 394,0691 & 8,908937 & 0,0000 \\
BP & 0,014128 & 0,005463 & 2,586216 & 0,0112 \\
R-squared & 0,999048 F-statistic & 32893,44 \\
& \multicolumn{3}{c}{ Prob(F-statistic) } & 0,000000 \\
\hline
\end{tabular}

Sumber : Data diolah, 2019

Hasil pengolahan data dengan menggunakan di peroleh regresi linier berganda untuk menghitung pendapatan petani di Kecamatan Pengabuan Kabupaten Tanjung Jabung Barat yang di pengaruhi dengan variabel bebas diantaranya produksi, harga dan biaya pengelolan. Persamaan regresi sebagai berikut :

\section{$\mathrm{Y}=\mathbf{- 2 . 8 9 8 . 3 1 5 + 7 9 4 . 0 7 3 6 P R O + 3 5 1 0 . 7 3 7 \mathrm { HJ } + 0 . 0 1 4 1 2 8 \mathrm { BP }}$}

Hasil pengolahan data di peroleh nilai konstanta sebesar 2.898.315 dan bertanda negative yang berarti jika produksi, harga dan biaya pengelolan bersifat tetap atau tidak berubah maka pendapatan petani kelapa dalam akan mengalami penurunan sebesar 2,9 juta rupiah. Koefisien regresi produksi sebesar 794,0736 dan bertanda positif artinya apabila produksi mengalami peningkatan sebesar 1 butir maka pendaptan petani kelapa dalam akan meningkat sebesar 794 rupiah. Koefisien regresi harga jual kelapa dalam sebesar 3510.737 dan bertanda positif artinya apabila terjadi peningkatan harga kelapa dalam maka pendaptan petani kelapa dalam akan bertambah sebanyak 3510,737 rupiah. Koefisien biaya pengelolaan sebesar 0,014128 dan bertanda positif artinya, apabila biaya pengelolaan mengalami peningkatan sebesar satu juta rupiah maka pendaptan petani kelapa dalam akan meningkat sebesar 14.128 rupiah.

\section{Pengujian hipotesis}

Uji simultan ( Uji F )

Uji $F$ digunakan untuk mengetahui semua variabel independen yang terdapat dalam persamaan regresi secara bersama-sama mempengaruhi variabel dependen. Pengujian dilakukan dengan membandingkan nilai $\mathrm{F}$ hitung dengan $\mathrm{F}$ tabel menggunakan 
tingkat keyakinan 90\% $(\alpha=10 \%)$. Hasil perhitungan diperoleh nilai $\mathrm{F}$ hitung sebesar 32893.44 dengan p-value sebesar 0.000000, dan nilai $F$ tabel sebesar 2,65. Oleh karena $F$ hitung $(665,7515)>\mathrm{F}$ tabel $(2,65)$ dapat disimpulkan bahwa terdapat pengaruh yang signifikan produksi kelapa dalam di Kecamatan Pengabuan Kabupaten Tanjung Jabung Barat pada tingkat keyakinan $90 \%$.

\section{Uji parsial (Uji t)}

Pengujian secara parsial atau uji t dimaksudkan untuk mengetahui apakah variabel-variabel independen secara sendiri-sendiri berpengaruh nyata atau tidak terhadap variabel dependen. Dalam penelitian ini menggunakan uji 2 arah. Dengan keyakinan 90\% $(\alpha=10 \%)$ serta derajat kebebasan (df) sebesar 92, maka $t$ tabel diperoleh 1,290. produksi (Pro) adalah sebesar 95.50746 dengan probabilita sebesar 0,0000. Nilai t-hitung $(95.50746)$ lebih besar dari t-tabel $(1,290)$ artinya produksi (Pro) berpengaruh secara signifikan terhadap produksi kelapa dalam di Kecamatan Pengabuan Kabupaten Tanjung Jabung Barat. Hal ini juga dapat dilihat dengan cara membandingkan nilai probabilita t-hitung dengan tingkat $\alpha=10 \%$. Nilai probabilita thitung $(0,0000)$ variabel produksi (Pro) lebih kecil dibandingkan dengan tingkat $\alpha=10 \%$, artinya variabel produksi (Pro) berpengaruh secara signifikan terhadap produksi kelapa dalam.harga jual (HJ) adalah sebesar 8.908937 dengan probabilita sebesar 0.0000. Nilai t-hitung $(8.908937)$ lebih kecil dari t-tabel $(1,290)$ artinya harga jual (HJ) berpengaruh secara signifikan terhadap produksi kelapa dalam di Kecamatan Pengabuan Kabupaten Tanjung Jabung Barat. Hal ini juga dapat dilihat dengan cara membandingkan nilai probabilita t-hitung dengan tingkat $\alpha=10 \%$. Nilai probabilita thitung (0.0000) variabel harga jual $(\mathrm{HJ})$ lebih besar dibandingkan dengan tingkat $\alpha=10 \%$, artinya variabel harga jual $(\mathrm{HJ})$ berpengaruh secara signifikan terhadap produksi kelapa dalam.biaya pengelolaan (BP) adalah sebesar 2.586216 dengan probabilita sebesar 0.0112. Nilai t-hitung 2.586216 lebih besar dari t-tabel $(1,290)$ artinya biaya pengelolaan (BP) berpengaruh secara signifikan terhadap produksi kelapa dalam di Kecamatan Pengabuan Kabupaten Tanjung Jabung Barat. Hal ini juga dapat dilihat dengan cara membandingkan nilai probabilita t-hitung dengan tingkat $\alpha=10 \%$. Nilai probabilita t-hitung (0.0112) variabel biaya pengelolaan (BP) lebih kecil dibandingkan dengan tingkat $\alpha=10 \%$, artinya variabel biaya pengelolaan (BP) berpengaruh secara signifikan terhadap produksi kelapa dalam.

\section{Koefisien determinasi $\left(\mathbf{R}^{2}\right)$}

Melalui koefisien Deteminasi (Adjusted R Square) dapat diketahui sejauh mana variabel luas lahan, tenaga kerja, jumlah pupuk, jumlah pestisida mampu mempengaruhi produksi kelapa dalam di Kecamatan Pengabuan Kabupaten Tanjung Jabung Barat. Semakin mendekati nilai 1 atau $100 \%$ maka semakin besar pengaruh variabel independen terhadap variabel dependen. Berdasarkan hasil regresi linier berganda diperoleh R-square sebesar 0.999048 atau 99,9\%. Hal ini menunjukkan bahwa persentase pengaruh variabel independen (luas lahan, tenaga kerja, jumlah penggunaan pupuk dan jumlah pembasmi hama) terhadap variabel dependen (produksi kelapa dalam) sebesar 99,9\%. Sedangkan $0,1 \%$ dipengaruhi oleh variabel yang belum diteliti dalam penelitian ini.

\section{Implikasi}

Produksi kelapa dalam di Kecamatan Pengabuan Kabupaten Tanjung Jabung Barat megalami peningkatan produksi kelapa dalam sebagai komoditi perkebunan untuk 
tingkat Kabupaten. Upaya peningkatan produksi kelapa dalam dipengaruhi oleh biaya pengelolaan, luas lahan dan tenaga kerja yang digunakan untuk mengelola pertanian masyarakat. Secara keseluruhan biaya pengelolaan dan luas lahan berpengaruh signifikan terhadap produksi kelapa dalam. Sedangkan tenaga kerja hanya sebagai faktor penunjang dalam pengelolaan dan upaya pemeliharaan serta pemanenan buah kelapa dalam tidak secara langsung dalam peningkatan produksi kelapa dalam di Kecamatan Pengabuan Kabupaten Tanjung Jabung Barat.

Berdasarkan hasil penelitian menunjukkan bahwa variabel-variabel yang mempengaruhi produksi kelapa dalam Kecamatan Pengabuan Kabupaten Tanjung Jabung Barat adalah biaya pengelolaan dan luas lahan berpengaruh posistif dan signifikan terhadap produksi kelapa dalam di Kecamatan Pengabuan Kabupaten Tanjung Jabung Barat. Sedangkan tenaga kerja berpengaruh negatif dan tidak signifikan terhadap produksi kelapa dalam di Kecamatan Pengabuan Kabupaten Tanjung Jabung Barat.

Produksi kelapa dalam di Kecamatan Pengabuan Kabupaten Tanjung Jabung Barat menjadi sumber produksi pertanian perkebunan terutama untuk jenis tanaman perkebunan kelapa dalam. Upaya pemenuhan kebutuhan komoditi pertanian perkebunan kelapa dalam sebagai komoditi ekspor guna kesejahteraan masyarakat Tanjung Jabung barat maupun Provinsi Jambi sedang digalakkan. Harapan petani di Kecamatan Pengabuan untuk diperhatikan dari segi permodalan untuk mengelola pertanian kelapa dalam dan setelah panen pun pemerintah kabupaten dapat membantu untuk memasarkan hasil panen. Adanya kerjasama antara pemerintah kabupaten dan petani diharapkan mampu memproduksi kelapa dalam yang lebih banyak dan lebih maksimal.

\section{KESIMPULAN DAN SARAN Kesimpulan}

Berdasarkan karakteristik sosial ekonomi petani kelapa dalam di Kecamatan Pengabuan Kabupaten Tanjung Jabung Barat terdapat perbedaan yang dapat dilihat dari kelompok responden berdasarkan jenis kelamin mayoritas jenis kelamin laki-laki sebesar 46 persen, tingkat pendidikan mayoritas dengan tingkat pendidikan SD, pengalaman kerja mayoritas kisaran antara 21-30 tahun sebesar 58 persen, mayoritas petani menggunakan biaya pengelolaan diatas Rp 3.001.000 sebesar 53 persen, dan mayoritas luas lahan yang dimiliki petani berkisar 1-4 hektar sebesar 59 persen, sedangkan mayoritas tenaga kerja yang dipakai antara 1-5 orang sebanyak 59 persen, serta mayoritas produksi kelapa dalam yang diperoleh petani diatas 21 ton sebesar 53 persen. Berdasarkan tingkat kepercayaan sebanyak $\alpha=10 \%$ hanya variabel luas lahan yang memiliki pengaruh yang signifikan terhadap produksi kelapa dalam di Kecamatan Pengabuan Kabupaten Tanjung Jabung Barat sedangkan variabel tenaga kerja, pupuk dan hama tidak berpengaruh secara signifikan terhadap produksi kelapa dalam di Kecamatan Pengabuan Kabupaten Tanjung Jabung Barat. Namun, secara serentak variabel terikat tersebut berpengaruh secara signifikan terhadap produksi kelapa dalam di Kecamatan Pengabuan Kabupaten Tanjung Jabung Barat. Dari segi pendapatan, produksi, harga jual, dan biaya pengelolaan berpengaruh secara signifikan terhadap pendapatan petani kelapa dalam di Kecamatan Pengabuan baik secara parsial maupun secara serentak. 


\section{Saran}

Pengaruh biaya pengelolaan dan luas lahan terhadap jumlah produksi kelapa dalam di Kecamatan Pengabuan Kabupaten Tanjung Jabung Barat sangat signifikan, disarankan untuk Pemerintah Kabupaten berperan aktif untuk membantu kelancaran petani dalam mengolah lahan dengan memberikan bantuan modal dan perluasan lahan serta pemasaran hasil panen kelapa dalam sebagai sumber komoditi unggulan asli daerah. Disarankan pada penelitian selanjutnya yang akan meneliti tentang produksi kelapa dalam disarankan untuk mencari tempat penelitian yang lebih luas baik lokasi maupun kelompok jenis kegiatan lainnya.

\section{DAFTAR PUSTAKA}

Amir, dkk. (2009). Metodologi Penelitian Ekonomi dan Penerapannya. Penerbit IPB: PRESS. Bogor.

Arianto, W. (2018). Analisis Faktor-Faktor yang Mempengaruhi Jumlah Produksi Kelapa Dalam di Desa Tungkal I Kecamatan Tungkal Ilir Kabupaten Tanjung Jabung Barat. Skripsi FE-UNJA. Universitas Jambi. Jambi

Artaman, D.M.A. (2015). Analisis Faktor-Faktor yang mempengaruhi pendapatan pedagang pasar seni sukawati di Kabupaten Gianyar. Tesis-FE UNUD. Universitas Udayana. Denpasar.

Bodieono. (2002). Ekonomi Mikro: Seri Sinopsis pengantar Ilmu Ekonomi No,1.Edisi 2, BPPE: Yogyakarta.

Firdaus, M. (2011). Ekonometrika Suatu Pendekatan Aplikatif. PT. Bumi Aksara: Jakarta

Kelana, Said. (1996). Teori ekonomi mikro. Rajawali Pres: Jakarta

Nazir, M. (2014). Metode Penelitian. Bogor: Ghalia Indonesia.

Soekartawi. (2003). Teori Ekonomi Produksi dengan Pokok Bahasan Analisis CobbDouglas. PT. Rajagrafindo Persada: Jakarta.

Sugiono. (2004). Statistik Menjadi Mudah 17. Elex Media Kompetindo: Jakarta

Sugiyono. (2011). Metode Penelitian Kuantitatif, Kualitatif dan $R \& D$, Penerbit Alfabeta: Bandung.

Sukirno, Sadono. (1985). Ekonomi Pembangunan. Bima Grafik: Jakarta.

Suparmi. (1986). Ekonomi Pertanian. Karunika Jakarta Universitas Terbuka: Jakarta Suparmoko. (2002). Ekonomi Publik Untuk Keuangan dan Pembangunan Daerah. Andi: Yogyakarta

Tasman, Aulia. (2007). Ekonomi Produksi Teori dan Aplikasi. Chandra Pratama.

Fajrin, M dan M. dan Muis, A. (2016). Analisis Produksi dan Pendapatan Usaha Tani

Kelapa Dalam di Desa Tindaki Kecamatan Pagiri Selatan Kabupaten Pagiri Moutung. E-J Agrotekbisnis Vol.4(2): Hal.210-216. 